\title{
Vínculos intertextuales entre los personajes de Pompeyo en Farsalia y de Héctor en Ilíada: macroestructuras textuales y configuración de los perfiles heroicos
}

\section{Introducción}

El argumento de Farsalia aborda la segunda Guerra Civil durante el siglo I a.C., en la que se enfrentaron Pompeyo, liderando las tropas del senado, y César, conduciendo tropas propias, por el control unipersonal del Estado. La temática histórica se reelabora de manera tal que queda estrechamente ligada a los avatares políticos del contexto de redacción, i.e. el gobierno de Nerón: mientras los tres primeros libros parecen simpatizar con el emperador, especialmente si se considera la dedicatoria a éste en I, 33-66 ${ }^{1}$, los siete siguientes, al parecer, se vuelcan ideológicamente a un fervoroso republicanismo y esgrimen duras críticas contra el régimen imperial ${ }^{2}$.

Si bien el presente trabajo no busca indagar las mutaciones ideológicas de Lucano en el proceso de redacción, mencionamos la existencia del problema en tanto nuestra propuesta de lectura trabaja sobre el supuesto de que el conjunto de la obra está

1 Es posible una lectura del elogio en clave irónica. En este sentido, vid. Ahl, F., Lucan: an introduction, Ithaca, Cornell University Press, 1976, 25-61.

2 Sobre el problema de la ideología en Lucano, es indispensable la consulta de Masters, J. Poetry and Civil War in Lucan's Bellum Civile, Cambridge, Cambridge University Press, 1992; Boissier, G., L'opposition sous les Césars, Paris, Hachette, 1875; ver especialmente Brisset, J., Les idées politiques de Lucain, París, Les Belles Lettres, 1964.

Al mismo tiempo, destacamos la idea de reelaboración de la materia histórica: nuestro trabajo concierne a la economía del relato en la medida en que la narración de Farsalia presenta una cadena de hechos organizados en secuencias; en ningún caso juzgaremos la naturaleza de las acciones de los personajes implicados en los acontecimientos históricos en tanto hechos del mundo fáctico de experiencia. 
“ideologizado". Si bien aceptamos, en consonancia con la tradición crítica marxista, que ningún texto está despojado de ideología ${ }^{3}$, destacamos que algunos son más explícitos que otros en este punto; Farsalia es un ejemplo, motivo por el cual ha sido leída como propaganda ${ }^{4}$. Esta propuesta se apoya en las libertades con las que Lucano elabora ciertos sucesos históricos ${ }^{5}$ y especialmente en los dos pasajes donde más evidente es esta elaboración: la narración de la batalla de Farsalia en el libro VII y la visita de César a Troya luego de triunfar sobre Pompeyo en el libro IX. Estas libertades tendrían por fin desarrollar el discurso antiimperialista y hacer explícito el fin "proselitista" de la redacción 6 .

Al mismo tiempo, la crítica ha detectado en la obra numerosos paralelismos con la épica homérica, en especial con la Ilíada ${ }^{7}$. En esta línea de trabajo, ha recibido especial

\footnotetext{
" Por "ideologizado" entendemos la relación intertextual del texto con otros textos explícitamente pertenecientes al campo del poder: las producciones historiográficas sobre la Guerra Civil y la doxa contemporánea a la redacción, es decir, aquellos discursos respecto de la administración del poder que hubieran circulado bajo el imperio de Nerón, en especial si tenemos en cuenta que Lucano perteneció al círculo íntimo del emperador y que fue obligado a suicidarse mientras redactaba la obra. Para la discusión sobre este problema, ver Johnson, W. R., Momentary Monsters: Lucan and his Heroes, Ithaca, Cornell University Press, 1987, y Bartsch, S., Ideology in Cold Blood: a Reading of Lucan's Civil War, London, Harvard University Press, 1997. Cf. Masters, Poetry and Civil War, 153-157 para un estado de la cuestión. 3 La propuesta teórica de Raymond Williams resulta ineludible a la hora de considerar esta clase de lecturas, especialmente desde la síntesis de la propuesta representada en Marxism and Literature, Oxford University Press, 1977.

4 vid. Masters, J., "Deceiving the reader: the political mission of Lucan's Bellum Civile 7", en Reflections of Nero: culture, history, \& representation, Chapell Hill, The University of North Carolina Press, 1994, 151-177 como sinopsis del tema y proyecciones.

5 Graves, R. (ed.), Lucan Pharsalia. Dramatic Episodes of the Civil Wars, West Drayton, Penguin Books, 1956; Syndikus, H.P., Lucans Gedicht vom Bürgerkrieg. Untersuchungen zur epischen Technik zu der Grundlagen des Werkes, (Diss.) Munich, 1958; Lintott, A. W., "Lucan and the History of the Civil War", $C Q$ 21, 2, 1971, 488-505; Johnson, Momentary Monsters; Masters, "Deceiving the reader" refuta estas lecturas y propone en cambio leer la explicitud del discurso politizado como una estrategia paródica.

6 Por "proselitista" entendemos un texto con una función pragmática explícita, a saber, el convencimiento respecto de ciertos ideales representados en la narración. Para profundizar la discusión, cfr. nota 2. Ver especialmente Masters, Poetry and Civil War, 153-157 para una sumaria revisión y confrontación de las principales lecturas politizadas de la obra, las cuales habilitarían el uso de cierto vocabulario específico, como "imperialismo" y "antiimperialismo" entre otros.

7 Respecto de los paralelismos entre Ilíada y Farsalia, ver especialmente Von Albrecht, M., "Der Dichter Lucan und die epische Tradition", FH 15, 1970, 267-308; Green, C. M. C., "Stimulos Dedit Aemula Virtus: Lucan and Homer Reconsidered", Phoenix 45, 1991, 234-249 (especialmente 232); Lausberg, M., "Lucan und Homer", ANRW 32.3., 1985, 1565-1622 Lebek, W. D., Lucans Pharsalia: Dichtungsstruktur und Zeitbezug, Hypomnemata 44, Göttingen, 1976; Pichon, R., Les Sources de Lucain, Paris, 1912 como detractor de esta lectura.
} 
atención el estudio comparado de los personajes de César y de Aquiles ${ }^{8}$. La equiparación ha sido ampliamente aceptada como válida, especialmente por su notoriedad ${ }^{9}$.

El personaje de Pompeyo, por otra parte, ha recibido un interés menor en el estudio de los paralelismos entre los dos poemas $^{10}$. Von Albrecht y Lausberg ${ }^{11}$ comparan el personaje de Pompeyo con el Agamenón de Ilíada, y a pesar de que los argumentos esgrimidos no logran ser convincentes ${ }^{12}$, el paralelo fue aceptado y no vuelto a revisar. Estos argumentos pueden sintetizarse en dos macro-argumentos. Por un lado, la obvia existencia de un contexto bélico de gran magnitud focalizado en un escenario puntual: Troya en el primer caso; Farsalia, como metonimia de las Guerras Civiles, en el segundo. Por otro lado, el enfrentamiento de dos líderes pertenecientes a una misma facción: Pompeyo y César eran romanos, así como Aquiles y Agamenón, aqueos ${ }^{13}$.

Nuestro trabajo se inserta en el marco de esta discusión. La literatura crítica ha dejado señalado un nicho respecto del lugar de Pompeyo en la lectura comparatista de Farsalia, pero la forma en que se construye su personaje no ha sido indagada con la misma profundidad con la que se han examinado otras áreas de la obra. Por este motivo, revisamos sumariamente la comparación de Pompeyo con Agamenón y proponemos una lectura alternativa trazando un paralelo entre Pompeyo y Héctor.

8 Johnson, Momentary Monsters y Ahl, Lucan dedican sendos capítulos exclusivamente al análisis del personaje de César. Su equiparación con Aquiles es trabajada fundamentalmente en von Albrecht, "Der Dichter" 269-308. Se revisa el problema en Green, "Stimulos Dedit"

9 Por citar un ejemplo, Ahl, Lucan, 155 sostiene que César se construye narrativamente como "a man confident in his strength, more sure of his purpose than Achilles himself, invincible in warfare, a man who will bring about a major change in Roman history".

10 De los trabajos que se han concentrado en Pompeyo y su dinámica con los "héroes" que disputan con él el protagonismo de la obra, destacamos a Ahl, Lucan que analiza a Pompeyo como antihéroe comparándolo con la épica post-homérica. De cualquier manera, afirma al respecto: "The Pharsalia, then, does not have a single, unifying hero as do the surviving epics that precede it. Rather, it has three paradigms of heroism, of which the most complex and least understood is Pompey" (156); según Johnson, Momentary Monsters, 85, "if the Pharsalia was to have had or could had a hero, that hero, that unreal, useless, unthinkable hero, would have to have been Pompey" (85).

$11^{12}$ Von Albrecht, "Der Dichter", 267-308; Lausberg, M., "Lucan und Homer”, ANRW 32.3. 1985, 1565 1622 .

12 Cf. Green, C. M. C., "Stimulos Dedit Aemula Virtus: Lucan and Homer Reconsidered”, Phoenix 45, 1991, 234-249 (especialmente 232).

13 El resumen de la argumentación completa puede recuperarse de Green, "Stimulos Dedit". 


\section{La comparación entre los personajes de Pompeyo en Farsalia y Agamenón en Iliada}

Desde nuestra lectura, la equiparación entre Pompeyo y Agamenón no es consistente en tanto Aquiles y Agamenón se convierten en adversarios perteneciendo ambos a una misma facción. Sin embargo, no eran ellos dos los únicos generales en el ejército aqueo. Obligados a combatir en Troya por el juramento hecho como condición para que Helena fuera desposada, se encontraban luchando idénticos en jerarquía Diomedes, Áyax, Teucro y Odiseo, por citar algunos de los capitanes que habían intentado en el pasado desposar a Helena. El hecho de que Ilíada narre la cólera de Aquiles contra Agamenón no implica una reducción de la cantidad de personajes involucrados en el conflicto.

La oposición entre los personajes de Pompeyo y César en Farsalia se genera por motivos muy distintos de los operantes en Ilíada, razón por el cual la búsqueda de antagonismos como calcos desvirtúa en última instancia la evidencia misma ${ }^{14}$. En Ilíada, los dos generales se enemistan mientras se desarrolla la guerra. Es decir, la guerra de grandes dimensiones es el fondo de la figura, el enfrentamiento de los dos generales. En Farsalia, en cambio, la guerra se coloca entre los antagonistas, como tema, y como consecuencia de la enemistad. La pertenencia de los personajes a una misma patria deja de ser una variable sobre la que construir un paralelo, puesto que el antagonismo se define a partir de ser causa del conflicto armado. E igualmente, la enemistad entre Aquiles y Agamenón no es el eje del relato ni el que mueve en última instancia el argumento ${ }^{15}$. Es simplemente el punto de partida de la cólera, pues a partir del canto VI, quien domina el escenario como antagonista de Aquiles es Héctor, el mejor de los troyanos, así como

14 Es la búsqueda de calcos lo que tiende a disuadir la realización de una lectura comparada: "Si, après avoir étudié les faits et les idées que renferme la Pharsale, on en examine la forme littéraire, et qu'on recherche quelles influences elle a subié, on s'aperçoit d'abord que, du côté de la Grèce, ces influences sont nulles ou à peu près. Je ne crois pas qu'on puisse citer un seul verse que Lucain ait directement emprunté à un poète hellénique, sans que ce vers ait déjà passé par les mains d'un auteur latin" (Pichon, 1912: 217).

15 Es necesario diferenciar el tema del poema, la ira sobrehumana de Aquiles presentada en el primer verso del poema como $\mu \tilde{\eta} v ı \zeta$, de los conflictos atravesados por la ira. Agamenón representa el disparador de la ira

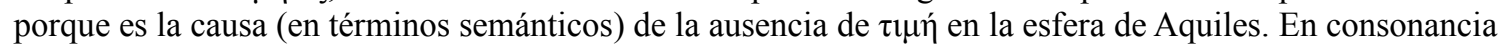
con Nagy (1997 [1980]), el gran problema de Ilíada es quién es el mejor de los aqueos, en tanto quién

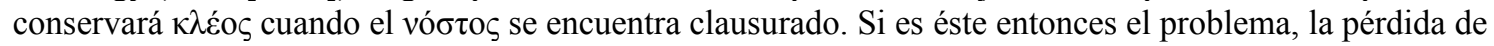
$\tau \iota \mu \eta ́$ es causa necesaria y suficiente para que la $\mu \tilde{\eta} v 1 \zeta$ crezca en Aquiles. 
Aquiles es el mejor de los Aqueos. Luego de la muerte de Patroclo, la rivalidad entre Aquiles y Agamenón se diluye y ya no vuelve a movilizar ningún conjunto de secuencias.

\section{El paralelo entre el personaje de Pompeyo en Farsalia y el de Héctor en Ilíada}

La macroestructura básica de Ilíada y de Farsalia es la enemistad de dos generales entre los cuales media un conflicto bélico. Por ese motivo, a la hora de buscar un paralelo entre Ilíada y Farsalia en la construcción del personaje de Pompeyo, nos parece indispensable determinar qué entendemos por personaje en términos estructurales. En sentido amplio, por "personaje" se entiende toda entidad humana o humanizada introducida en una obra de ficción narrativa; en sentido estricto, el término queda restringido a los participantes del dominio narrado, del mundo narrativo, lo cual excluye la figura del narrador $^{16}$. El estructuralismo afirma que la fuente principal de nuestra comprensión del personaje de ficción debe ser encontrada en elementos que son específicos del texto ${ }^{17}$. En otras palabras, se afirma que el personaje es una construcción textual, la acumulación de un conjunto de rasgos discretos bajo una etiqueta identificatoria o nombre propio ${ }^{18}$.

Recuperando este modo de concebir la categoría de "personaje", en tanto constructo textual, nos proponemos organizar alrededor de cada uno de los dos personajes implicados en

16 Margolin, U., "The what, the when and the how of being a character in Literary Narrative", Style 24, No.3, 1990, 453-68, esp. 53; "Character", en Herman, D. \& M. Jahn, M. Ryan (Ed), Routledge Encyclopedia of Narrative Theory. Routledge, 2005, 53-7, esp. 66.

El personaje debe ser entendido ante todo como "a theory-dependent conceptual construct or theoretical object, of which several alternative versions exist in contemporary poetics. [...] Literary character suggest an individual made up from words, textually identified by referring expressions, invented by an author for some purpose, such as creating certain effects or conveying some message." 453.

17 Cf. Mead, G., "The representation of the fictional character", Style 24, 3, 1990, 440-452.

18 "Cuando semas idénticos atraviesan repetidamente el mismo Nombre propio y parecen adherirse a él, nace un personaje. Por lo tanto, el personaje es un producto combinatorio: la combinación es relativamente estable (está marcada por el retorno de los semas) y más o menos compleja (comporta rasgos más o menos congruentes, más o menos contradictorios); esta complejidad determina la "personalidad" del personaje, tan combinatoria como el sabor de una comida o el aroma de un vino. El nombre propio funciona como el campo de imantación de los semas; al remitir virtualmente a un cuerpo, arrastra la configuración sémica a un tiempo evolutivo (biográfico).” Barthes, R., S/Z, Buenos Aires, Siglo XXI Editores, 2004 (1970), 55.

La formalización de la categoría "personaje" a partir de la centralización de sus rasgos en torno al nombre propio puede ser representada en la siguiente fórmula:

$$
\mathrm{P}(\mathrm{x})=\{\mathrm{e}, \mathrm{f}, \mathrm{g}, \ldots \mathrm{n}\}
$$$$
\text { Personaje (nombre propio) }=\mathrm{P}(\mathrm{x})
$$ 
nuestro análisis, Pompeyo y Héctor, un conjunto de cinco rasgos que los definen como sendos conjuntos análogos:

\section{1- Estricta moral}

2- Ausencia de una causa justa

3- Hombre amante

4- Error trágico

5- Circunstancias de la muerte

\section{1- Portador de una estricta moral}

Ambos personajes se definen por ser portadores de una estricta moral por oposición a sus antagonistas, que son definidos como personajes egocéntricos e irrefrenables en el cumplimiento de sus metas individuales: así como Aquiles solicita a su madre Tetis en I, 407-412 que los demás aqueos sean destruidos hasta que reparen sus ofensas, César se presenta en I, 146-147 como un individuo caracterizado por ser movimiento continuo, "as a process in nature" $" 19$.

acer et indomitus, quo spes quoque ira uocasset, ferre manum et numquam temerando parcere ferro $(\mathrm{I}, 146-147)^{20}$

Impetuoso e indomable, a donde lo hubieran llamado la esperanza y la ira, llevaba su mano y nunca se abstenía de manchar el hierro.

Poco más adelante, Héctor vacila en la batalla y a diferencia de Aquiles es invadido por el miedo. En V, 470 los troyanos se han replegado y ceden el frente de batalla. Sarpedón entonces amonesta a Héctor:

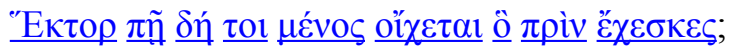

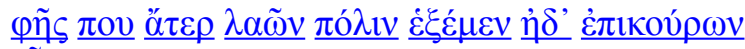

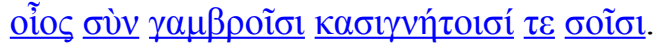

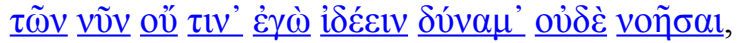

19 Johnson, "Momentary Monsters", 74.

20 Citamos el texto latino a partir de Duff, J. D., Lucan: the Civil War, Loeb Classical Library, Cambridge, Mass. and London, Cambridge University Press, 1928. Las traducciones castellanas nos pertenecen. 


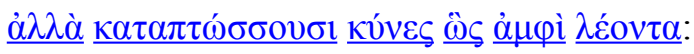

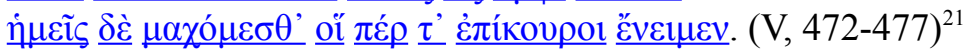

¿Héctor, a dónde se te ha ido la furia y el ánimo que antes tenías? Aseguras que conservarás la ciudad sin huestes y sin aliados, tú solo, con tus cuñados y con tus hermanos. Pero de ésos no soy capaz ahora de ver ni notar a ninguno, pues se amedrentan como perros en torno de un león, y los que luchamos somos los que estamos aquí como aliados (...). ${ }^{22}$

Héctor se siente afectado por la amonestación y vuelve a la batalla con renovada furia:

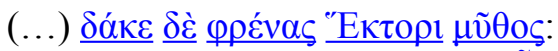

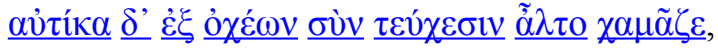

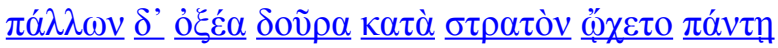

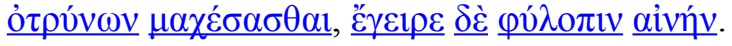

(...) la reprimenda mordió a Héctor las mientes. Al punto saltó del carro a tierra con las armas y blandiendo agudas lanzas recorrió el ejército por doquier, instándolos a luchar, y despertó una atroz contienda. (V, 493-496).

Cuando en el canto sexto Agamenón y Néstor estimulan la furia de los guerreros para obligar a Héctor y sus fuerzas a replegarse mientras éstos se encuentran en retirada atemorizados, Héleno los disuade de regresar a la ciudad. Se dirige especialmente a Héctor y a Eneas, a quienes llama "los mejores para toda empresa, bien para luchar, bien para decidir" (6.78-9). Envía a Héctor a la ciudad para encargar a Hécuba la realización de ciertos sacrificios (6.86-101).

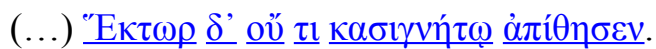

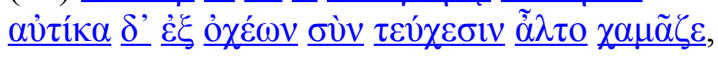

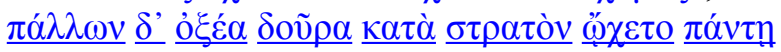

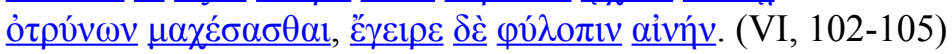

(...) Héctor no desobedeció a su hermano. Al punto del carro saltó a tierra con las armas blandiendo las agudas lanzas, recorrió el ejército por doquier instándolos a luchar y despertó una atroz contienda.

21 Citamos el texto en griego de Iliada a partir de Monro, D. \& T. Allen (ed.), Homer. Homeri Opera in five volumes, Oxford, Oxford University Press, 1920.

22 Citamos la traducción de Ilíada desde la edición de Crespo Güemes, E. (ed.), Homero, Ilíada, Madrid, Gredos, 1996. 
Cuando regresa a la ciudad y se encuentra con Hécuba, rechaza la posibilidad de descansar:

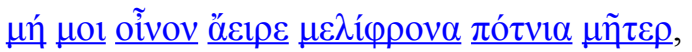

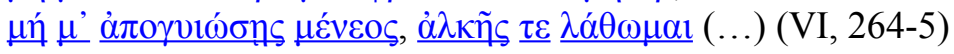

No me ofrezcas vino, dulce para las mientes, augusta madre, no sea que me relajes la furia y me olvide del coraje.

Así se mantiene fiel a sus obligaciones como guerrero. Agrega:

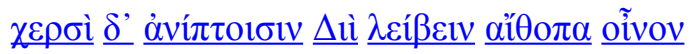

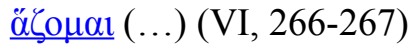

Hacer libaciones de rutilante vino para Zeus con manos sin lavar me causa escrúpulos (...).

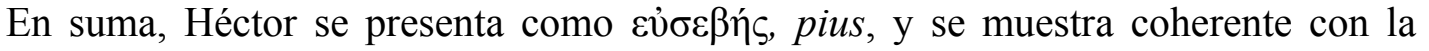
sanción dirigida a su hermano en III, 50. Su $\varepsilon v ̉ \sigma \varepsilon ́ \beta \varepsilon 1 \alpha$ se construye sobre el respeto a los dioses y a los maiora, lo cual se traduce en que su función social sea la protección de la

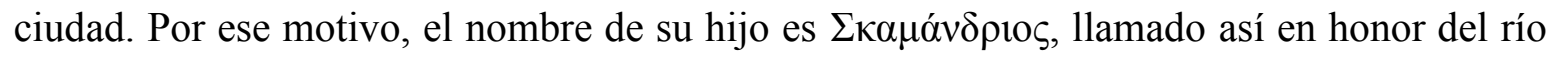

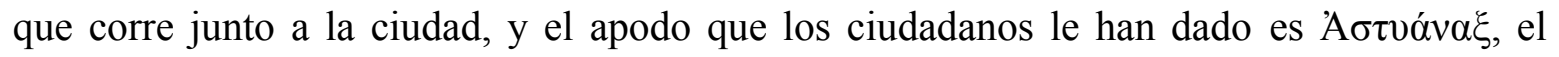
"protector de la ciudad ${ }^{23}$ " haciendo alusión a la principal función de Héctor en la comunidad:

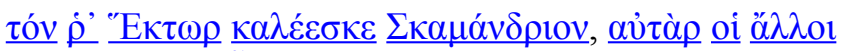

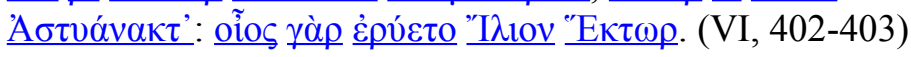

Héctor solía llamarlo Escamandrio, pero los demás Astianacte; pues Héctor era el único que protegía Ilio.

23 Recordamos que el nombre propio es parlante, es decir, la lexicalización de una descripción definida, de la

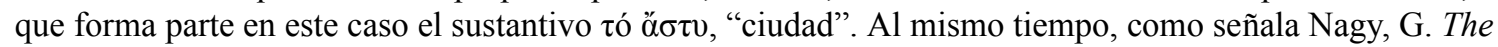
Best of Achaeans, The Johns Hopkins University Press, 1999 (1979), 218, el nombre de Héctor también es parlante, en tanto es resultado de la gramaticalización del verbo ह̌ $\chi \omega$, que en una de sus acepciones significa "proteger". 
Sin embargo, la estricta moral no libera al personaje de la ambigüedad ética que lo caracteriza como humano ${ }^{24}$. Tanto Aquiles como César son presentados como personajes que, ya por su naturaleza híbrida, en el caso de Aquiles, ya por su ambición sobrenatural en el caso de $\mathrm{César}^{25}$, se colocan en un plano por encima de lo humano. Esta fortaleza desmesurada motivará que tanto César como Aquiles sean personajes monolíticos en contraste con sus antagonistas ${ }^{26}$. Es esta humanidad la que convierte a Héctor y a Pompeyo en personajes trágicos, representación de individuos que han puesto su vida al servicio de su comunidad y aceptan sobre ellos las enormes expectativas de aquellos por los que van a

24 La cambiante representación del personaje de Pompeyo se atribuye a su humanidad: la posibilidad de (en términos de Redfield, J., Naturaleza y Cultura en la Ilíada: La Tragedia de Héctor, Barcelona, Destino, 1992 [1975]) errar en la toma de decisiones y provocar la precipitación de la tragedia por ello: "Pompey is simply a human, with his own strengths and weaknesses" (Bartsch, "Ideology", 76) "His heavily rhetorical claims of moral superiority have already been undermined by his characterization in the text" (77). Acerca del problema de la incoherente representación del personaje, ver Green, C. M. C., "The Necessary Murder: Myth, Ritual, and Civil War in Lucan, Book 3", CA 13, 1994, 203-233.

25 La sobrenaturalidad del personaje de César se consolida en la travesía que realiza hacia el Epiro en medio de una tempestad, anunciada con múltiples y terribles signos a los cuales subestima. Si alguna divinidad existiera en Farsalia, es sometida por el poder de César:

mihi funere nullo/ est opus, o superi: lacerum retinete cadauer/ fluctibus in mediis, desint mihi busta rogusque,/ dum metuar semper terraque expecter ab omni.'/ haec fatum decimus, dictu mirabile, fluctus/ inualida cum puppe leuat, nec rursus ab alto/ aggere deiecit pelagi sed pertulit unda/ scruposisque angusta uacant ubi litora saxis/ inposuit terrae. pariter tot regna, tot urbes/ fortunamque suam tacta tellure recepit. (V, 668-677)

“(...) No tengo funeral alguno, o dioses: retengan mi cadáver mutilado en el medio de las olas, que me falten las piras funerarias y el sepulcro, mientras siempre sea temido y sea esperado por toda la tierra." Habiendo dicho estas cosas, maravilloso de decir, una ola lo levanta con su frágil popa, y no lo arrojó de nuevo desde lo alto contra la muralla del mar, sino que lo llevó la ola y lo depositó en la tierra, en donde las angostas costas se ven libres de afiladas rocas. Habiendo sido tocada la tierra, recuperó al mismo tiempo tantos reinos, tantas ciudades y su suerte.

26 Tanto César como Aquiles presentan también rasgos humanos: Aquiles, el aió́ৎ que comienza a quebrar su postura en la embajada apaciguadora durante el canto IX y el dolor ante la muerte de Patroclo; César, el pavor que lo invade cuando llega a Egipto en X. Sin embargo, estos rasgos no los ponen en conflicto con sus propias misiones. César es presentado en el libro I sed non in Caesare tantum/nomen erat nec fama ducis, sed nescia virtus/ stare loco, solusque pudor non vincere bello (I, 143-145), "Pero en César no existía tanto el nombre y la fama de general, sino una virtus ignorante de reposar en un mismo lugar, y su único pudor era no vencer en la batalla". 
$\operatorname{morir}^{27}$. Es esta humanidad la que motiva lo que ha sido leído como "ambigüedad ética"28, que incluso es tematizada en Farsalia en el discurso de Catón (IX, 190-206)

\author{
'ciuis obit' inquit 'multum maioribus inpar \\ nosse modum iuris, sed in hoc tamen utilis aeuo, \\ cui non ulla fuit iusti reuerentia; salua \\ libertate potens, et solus plebe parata \\ priuatus seruire sibi, rectorque senatus, \\ sed regnantis, erat. nil belli iure poposcit, \\ quaeque dari uoluit uoluit sibi posse negari. \\ inmodicas possedit opes, sed plura retentis \\ intulit. inuasit ferrum, sed ponere norat. \\ praetulit arma togae, sed pacem armatus amauit. \\ iuuit sumpta ducem, iuuit dimissa potestas. \\ casta domus luxuque carens corruptaque numquam \\ fortuna domini. clarum et uenerabile nomen \\ gentibus et multum nostrae quod proderat urbi. \\ olim uera fides Sulla Marioque receptis \\ libertatis obit: Pompeio rebus adempto \\ nunc et ficta perit (...)"
}

Ha muerto un ciudadano- dijo [Catón]- muy distinto a los mayores en conocer los límites de lo legal, pero sin embargo útil en nuestra era, que no ha tenido ningún respeto por la justicia; poderoso conservando la libertad, y él solo [se mantuvo como] particular mientras la gente estaba dispuesta a servirle; era el jefe del senado, pero [de un senado] soberano. Nada reclamó por ley de la guerra, todo lo que quiso que se le diera, quiso que se le pudiera negar. Poseyó riquezas desmedidas, pero ingresó más de las que retuvo. Blandió el hierro, pero había sabido deponerlo. Prefirió las armas a la toga, pero, armado, amó la paz. El

27 Respecto de Pompeyo, "He was, for the most part against his will, the magnet toward which the fantasies of his contemporaries (...) felt themselves irresistibly drawn" (Johnson, "Momentary Monsters", 85). Si bien Catón afirma que nec, si fortuna fauebit,/ hunc quoque totius sibi ius promittere mundi/ non bene conpertum est (II, 320-322), "Y se evidencia que, si la fortuna lo favorece, él también se promete el control del mundo entero", debe tenerse en cuenta que existe una evolución de los personajes a lo largo de la obra, en sus propios rasgos y, en el caso de la relación entre Catón y Pompeyo, a nuestro entender, respecto del juicio de uno sobre otro. Por este motivo, proponemos leer dialógicamente II, 320-322 y IX, 190-206, citado a continuación del segmento del que se desprende esta nota. Al mismo tiempo, recordamos que cuando en el libro 1 se presenta el conflicto y a los personajes, el narrador sienta como bases del conflicto los particulares intereses de las partes implicadas y también, en la misma medida, la predisposición de la sociedad entera a entrar en un conflicto de estas características: Hae ducibus causae; suberant sed publica belli/ semina, quae populos Semper mersere potentis (I, 158-159), "Éstas eran las causas de los generales; pero subyacían semillas de guerra en la sociedad".

Por otro lado, en relación con Héctor: "El papel social de Héctor exige de él más que sumisión, exige que tenga iniciativa, que mande y que decida. Decidir entraña la posibilidad de equivocarse, y puesto que el hombre es mortal, sus errores son irremediables. No obstante, sin libertad y por lo tanto sin la posibilidad de error, no hay heroísmo." (Redfield, Naturaleza y Cultura, 99)

28 Ahl, Lucan, 153 toma la ambigüedad ética del personaje como rasgo esencial de su condición de antihéroe. "He is neither good nor evil; nor is he strong or invincible. But he has his own curious kind of greatness." Johnson, Momentary Monsters, XI propone pensar los héroes de Farsalia como caricaturas de héroes. 
poder le fue útil como general, asumido y abandonado. Casto fue su hogar, carente de lujo y nunca corrompido por la suerte de su señor. Famoso y venerable fue su nombre entre las gentes y mucho fue lo que ayudó a nuestra ciudad. Tiempo atrás, al ser admitidos Silla y Mario, murió la verdadera fe en la libertad: desaparecido Pompeyo, ahora perece también la ficción hecha de estas cosas.

\section{2- Ausencia de una causa justa}

Las empresas que ambos defienden no son objetivamente justas y ambos personajes son conscientes de ello. Por una parte, Héctor no olvida las causas primeras del conflicto. Cuando en III, 38-57 ve a Paris retrocediendo ante el avance de Menelao, lo amonesta haciendo referencia a la conducta que de él se espera; al mismo tiempo, explicita la inmoralidad de las causas del conflicto:

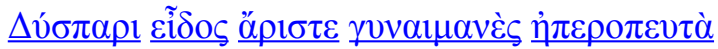

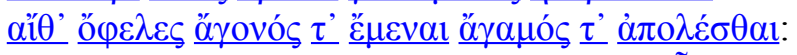

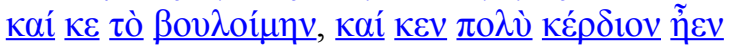

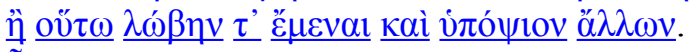

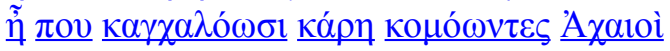

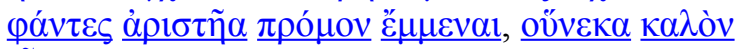

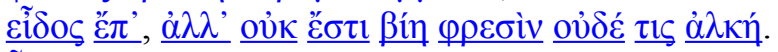

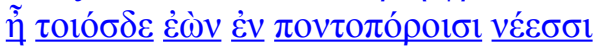

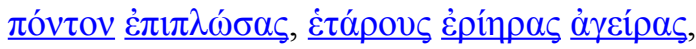

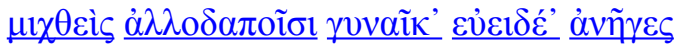

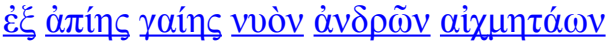

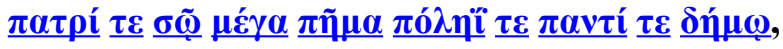

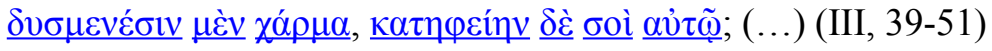

¡Calamidad de Paris, presumido, mujeriego y mirón! ¡Ojalá no hubieras llegado a nacer o hubieses muerto célibe! ¡Incluso eso habría preferido -y mucho más habría valido-, antes que volverte así afrenta y oprobio de los demás! A carcajadas seguro que ríen los aqueos, de melenuda cabeza, que creían que eras paladín y campeón, porque es bella tu apariencia; pero en tus mientes no hay ni fuerza ni coraje. ¿Siendo de esa calaña, en las naves, surcadoras del ponto, navegaste sobre el mar tras reunir muy fieles compañeros, te mezclaste con extranjeros y con la hermosa mujer zarpaste desde remota tierra, con la nuera de belicosos lanceros, enorme calamidad para tu padre, tu ciudad y todo tu pueblo, irrisión para los enemigos y escarnio para ti mismo? (el destacado es nuestro) 
Se entiende que su participación en la batalla tiene menos que ver con su propio

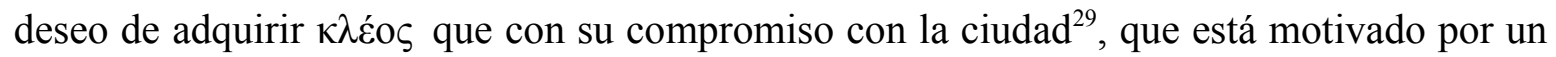
intenso $\alpha i \delta \omega \varsigma^{30}$.

En este punto ambos personajes se oponen de manera complementaria; en otras palabras, si bien se conducen de maneras opuestas, en esa oposición revelan sus puntos de contacto. Mientras Héctor se desarrolla como un guerrero ejemplar que incluso se presenta como superior a Aquiles ${ }^{31}$, Pompeyo progresivamente se repliega sobre sí y llega a las vísperas de la batalla de Farsalia sumido en la inacción. Sus tropas, representadas en VII por Cicerón, lo empujan al combate tematizando el $\alpha i \delta \omega ́ \varsigma$ para intentar convertirlo en vé $\mu \varepsilon \sigma i \varsigma$.

quo tibi feruor abit aut quo fiducia fati?

de superis, ingrate, times causamque senatus credere dis dubitas? ipsae tua signa reuellent prosilientque acies: pudeat uicisse coactum. (VII, 75-78)

¿A dónde se te ha ido el fervor o a dónde tu confianza en el destino? ¿Temes acaso, ingrato, a los dioses y dudas confiar a los dioses la causa del senado? Tus tropas por ellas mismas arrancarán tus estandartes y se lanzarán hacia adelante: deberías avergonzarte de vencer forzado a hacerlo.

Si leemos a Pompeyo como un héroe post-homérico, portador de rasgos antiheroicos y propios de un personaje trágico ${ }^{32}$, su inacción es consecuencia de la tensión ética

\footnotetext{
"K $\lambda \dot{\text { ó} \varsigma, ~ " f a m a ", ~ " g l o r i a ", ~ u n ~ t e ́ r m i n o ~ i m p o r t a n t e ~ d e n t r o ~ d e l ~ m u d o ~ h e r o i c o ~ t a l ~ y ~ c o r n o ~ s e ~ r e p r e s e n t a ~ e n ~ l a ~}$

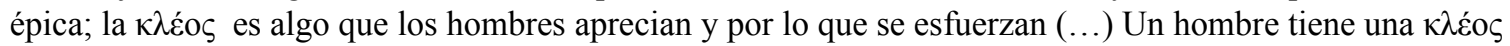
que es su "reputación", bien sea en general o bien sea por una cualidad particular." (Redfield, Naturaleza y Cultura, 32).

29 Recordamos en este punto lo desarrollado en el apartado precedente sobre el nombre de su hijo, Astianacte.

$30 \mathrm{Si}$ bien Héctor en presentado en los cantos 1 y 2, éste es el primer momento en el poema en el que Héctor habla. El contenido de su intervención resulta clave para entender al personaje, pues en él vehicula los semas que lo definirán como personaje, relacionados con la ética y la moral ciudadanas más que con el mundo de los guerreros.

Por otro lado, el concepto de $\alpha i \delta \omega ́ \varsigma s$ se entiende como el temor al juicio de los demás, en ocasiones puede ser paralizante si se convierte en miedo o, como sucede en Héctor, se convierte en el sentimiento movilizador de acciones, vé $\mu \varepsilon \sigma ı$ (Redfield, Naturaleza y Cultura, 91).

31 Esta superioridad de Héctor será explicada en el apartado 5. Circunstancias de la muerte.

32 Ahl, Lucan, 153, "The post-homeric hero is heavily colored by his tragic dimension (...) He becomes something of an anti-hero" a partir de Lawall, G., "Jason as anti-hero", YCIS 19, 1966, 119-169, el antihéroe se piensa en términos opuestos al modelo odiseico. El antihéroe es $\alpha \mu \eta \dot{\chi} \chi \alpha v o \varsigma$.
} 
que lo invade. Pompeyo es consciente de la criminalidad de la causa por la que lucha y de estar obligado por aỉó́s a conducir las tropas del senado. Sabe que sea cual fuere el resultado, éste será infame.

omne malum uicti, quod sors feret ultima rerum, omne nefas uictoris erit. (VII, 122-123)

Que todo mal que la postrera suerte de las cosas depare sea para el vencido; toda abominación, para el vencedor.

Por esto, Pompeyo representa un puente entre los personajes de César y Catón, los otros dos héroes de Farsalia ${ }^{33}$. Mientras éstos son pura acción y sólo conciben el compromiso total con sus fines ${ }^{34}$, Pompeyo se define por ser lo opuesto: es el líder de la causa republicana no motu proprio sino porque fue elegido a causa de sus pasados triunfos ${ }^{35}$. Cicerón le reprocha en Farsalia su falta de convicción como líder ${ }^{36}$ :

(...) scire senatus auet, miles te, Magne, sequatur an comes. (VII, 83-5)

(...) el senado ansía saber, Magno, si te seguirá como soldado o como acompañante

33 Cf. Ahl, Lucan.

34 "For they are viewed in terms of an ideal: the quest for personal power, the struggle for virtue" (Ahl, Lucan, 160)

35 Cf. n. 13, Johnson, Momentary Monsters, 85. Al mismo tiempo, la presentación de Pompeyo en I, 121-122 destaca sus éxitos como un rasgo relevante en la construcción del personaje: $t u$, nova ne veteres obscurent acta triumphos/ et victis cedat piratica laurea Gallis, Magni, times; "Tú, Magno, temes que los nuevos acontecimientos oscurezcan tus antiguos triunfos y que el laurel pirático ceda ante los vencidos galos", si bien el tópico sustenta en este punto la imagen de un Pompeyo soberbio (I, 123-124), te iam series ususque laborum/ erigit inpatiensque loci fortuna secundi, "a ti te enorgullece la serie y la costumbre de tus proezas, y la fortuna que no soporta el segundo lugar".

36 Nuevamente, un pasaje en el que Lucano se aleja de la fidelidad a los hechos en pos de la construcción de una secuencia elocuente en sí misma. Cicerón no estuvo presente en la batalla de Farsalia, pero su presencia en este escenario funciona performativamente, a la manera de una metonimia por el senado. Todo el pasaje resulta sumamente económico en su construcción desde el momento en que soluciona en la dimensión espacial -casi una puesta en escena- un problema del plano de lo conceptual: las presiones que llevan al personaje a precipitar los acontecimientos. En otras palabras, se realiza en el plano de lo visible, que es lo que puede ser narrado en el contexto de la épica, el fuero interno del personaje. Si es válido el anacronismo, estamos frente a una estrategia narrativa propia de los movimientos de vanguardia del siglo XX. 
A lo que Pompeyo responde aceptando sus obligaciones y tematizando la tensión que lo paraliza en el conocimiento de la ausencia de nobleza en los eventos venideros:

testor, Roma, tamen Magnum quo cuncta perirent accepisse diem (VII, 91-92)

Testifico sin embargo ante ti, Roma, que [Pompeyo] Magno aceptó como imposición el día en que todo pereció

\section{3- Hombre amante}

Héctor se diferencia de los demás héroes de Ilíada en que se comporta en relación con su esposa, Andrómaca, como un amante esposo. En este aspecto se distancia incluso de Aquiles: a pesar de que su ira se despierta cuando Agamenón toma a Briseida para sí, la relación que guarda con ella es diametralmente distinta a la que Héctor posee con Andrómaca. Mientras en la esfera de Aquiles Briseida es un trofeo de guerra, un elemento contextual dispuesto para tematizar su $\tau \mu \eta^{\prime 37}$, Andrómaca representa en la esfera de Héctor su compromiso con la ciudad, en tanto su compromiso familiar funciona como metonimia. El espacio dedicado en la narración a la descripción del último encuentro que mantienen los esposos tiene por fin al mismo tiempo la construcción de la "etopeya" de Héctor, es decir una secuencia rica en patetismo cuya función narrativa es mostrar el ethos del personaje desde su performance en una situación concreta. Si se enfrenta a un personaje monolítico que participa más de la ética de los dioses que de los hombres, por contraste Héctor se define por ser hombre, y es su humanidad, como se afirmó antes, la que lo configura como héroe trágico.

Pompeyo por su parte también es presentado como un amante esposo. En las vísperas de Farsalia, Cornelia despierta en la noche y encuentra a Pompeyo llorando. Él entonces comparte con ella sus miedos y se muestra en toda su fragilidad, extraña en un personaje épico.

37 Honor del héroe pensado relacionalmente con la comunidad de guerreros en la que se inserta. Se representa simbólicamente en objetos o conductas de los demás hacia el héroe representando la valoración que de éste tiene su comunidad. 
nocte sub extrema pulso torpore quietis dum fouet amplexu grauidum Cornelia curis pectus et auersi petit oscula grata mariti, umentis mirata genas percussaque caeco uolnere non audet flentem deprendere Magnum. (V, 734-738)

Cornelia, al final de la noche, expulsada la pesadez del sueño, mientras con su abrazo da calor al pecho cargado de preocupaciones y reclama los dulces besos de su marido que le da la espalda, habiendo admirado sus humedecidas mejillas y sacudida por un dolor indescriptible, no osa sorprender a Magno mientras llora.

La escena, tal como sostiene $\mathrm{Ahl}^{38}$ es uno de los raros momentos de acercamiento y calidez humanos en toda la épica latina, y desde nuestra lectura, el sentido de la secuencia es análogo a la despedida de Héctor y Andrómaca en tanto su función narrativa es construir la etopeya de Pompeyo. Ésta se realiza por contraste con la etopeya de César, también desarrollada en el canto V. Se narra cómo a lo largo de trescientos veinte versos César desafía a la tempestad para volver al Epiro. La secuencia, sin embargo, a pesar de su extensión, no tiene incidencia en el desarrollo del argumento en tanto no es condición previa para la sucesión causal de secuencias posteriores. Por este motivo, todo el conjunto en la economía de la narración se inserta como catálisis $^{39}$. La función de ambas escenas, no casualmente integradas en un mismo canto, es contraponer a los personajes desde su humanidad $^{40}$.

38 Ahl, Lucan, 107.

39 Según Barthes (1966) estas secuencias o conjunto de secuencias son unidades descriptivas con funcionalidad parásita a los núcleos, unidades de acción consecutivas y consecuentes. Su funcionalidad sin embargo es clave para la comprensión de los núcleos en tanto, en términos "relevantistas" (Wilson \& Sperber, "Sobre la definición de relevancia", en: Valdez Villanueva, L. (ed.), La búsqueda del significado, Madrid, Tecnos, 583-98) construye contextos sobre los cuales procesar los núcleos.

$40 \mathrm{La}$ imagen que queda de César luego de la tempestad es la del impío que quizás a causa de su impiedad doblega a la naturaleza.

fisus cuncta sibi cessura pericula Caesar/ 'sperne minas' inquit 'pelagi uentoque furenti/ trade sinum. Italiam si caelo auctore recusas/ me pete (V, 577-580)

César, confiado en que todos los peligros habían de cesar ante él, afirma "Ignora las amenazas y despliega las velas al furioso viento del mar. Si rehúsas dirigirte a Italia siendo el cielo la causa, búscame a mí.

El episodio actualiza la impiedad de César en III, 399-452. Cuando ordena derribar el bosque sagrado y ninguno de sus hombres se atreve a hacerlo, él mismo toma un hacha y tala la primera encima, luego de lo cual dice: iam nequis vestrum dubitet subvertere silvam/ credite me fecisse nefas, "Que ya 
Al mismo tiempo, el diseño del personaje desde su condición de marido amante se refuerza por la descripción de sus respectivas esposas y por la manera en que ellas viven el dolor y la muerte de estos. Cornelia y Andrómaca lloran y se lamentan incluso cuando nada parece asegurar la muerte inminente de sus esposos. Héctor busca a Andrómaca en su casa y no la encuentra porque ésa se había dirigido hacia las murallas, donde lloraba por él (VI, 373). Mientras Andrómoca es presentada como "intachable esposa" (374), Cornelia es por su parte fida comes Magni, "fiel compañera del Magno" (V, 804), y cuando éste le dice que ha llegado la hora de separarse y que ella debe partir por su propia seguridad a Mitilene, el narrador describe una Cornelia que se derrumba:

(...) uix tantum infirma dolorem

cepit, et attonito cesserunt pectore sensus. (V, 759-760)

Apenas pudo, debilitada, dar cabida a un dolor tan grande, y los sentidos huyeron de su pecho estupefacto.

En este sentido se interpreta la exclamación del narrador cuando se dispone a narrar la última noche de Pompeyo junto a Cornelia ${ }^{41}$ :

heu, quantum mentes dominatur in aequas

iusta Venus! (V, 727-728)

cuán grande poder tiene Venus sobre los corazones justos!

\section{4- Error trágico}

En la economía narrativa de Ilíada, Héctor es funcional a Aquiles, cuya $\mu \tilde{\eta} v i \varsigma$ lo lleva a retirarse del combate para ejercer presión sobre Agamenón. Los avances de Héctor,

\footnotetext{
ninguno de vosotros dude en derribar el bosque, sepan que yo he cometido el sacrilegio."

Es necesario aclarar que, si bien el bosque en cuestión es un bosque galo y que, en consecuencia, los dioses que allí residen no forman parte del panteón romano, la economía del texto presenta la secuencia de manera tal que hace inferir si no una crítica al menos un distanciamiento (aún mayor) del narrador respecto de las acciones de los personajes en lo que al cumplimento de los mores respecta.

41 Si bien vuelven a encontrarse cuando Pompeyo va a buscarla a Lesbos, el Pompeyo que allí aparece ha cambiado luego de Farsalia: ha muerto el héroe y queda un fugitivo que no tardará en morir. Por ese motivo, la escena previa a Farsalia debe, a nuestro juicio, ser leída como la despedida simbólica de los esposos.
} 
avalados por los $\operatorname{dioses}^{42}$, obligan a los aqueos a replegarse y obligan a Agamenón a suplicar a Aquiles que regrese al combate, situación desesperada que se representa performativamente con la embajada de Odiseo, Áyax y Fénix ante Aquiles en el canto 9. Pero Héctor excede los límites: luego de incendiar las naves y de matar a Patroclo, lo despoja de la armadura, perteneciente a Aquiles, y se viste con ella ${ }^{43}$, gesto que en la economía de la narración opera como "error trágico".

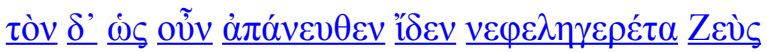

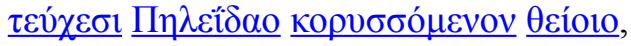

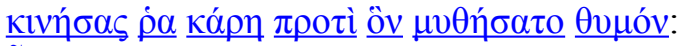

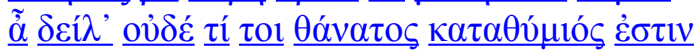

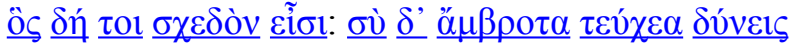

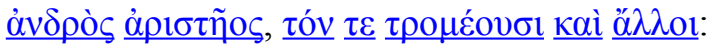

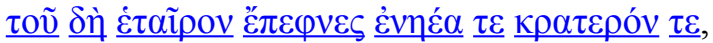

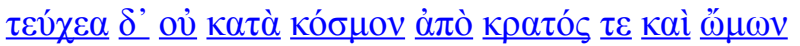

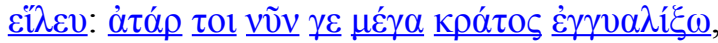

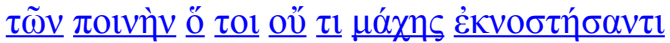

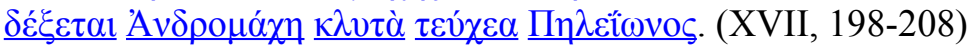

Cuando Zeus, que las nubes acumula, lo vio de lejos vistiéndose con las armas del divino Pelida, comenzó a menear la cabeza y dijo así a su propio animo: “¡Desdichado! La muerte está bien ausente de tu ánimo, mas ya se aproxima a ti. Te vistes con las inmortales armas del más bravo guerrero, de quien también los demás tiemblan, has matado a su amable y esforzado compañero, y las armas de la cabeza y de los hombros vilmente le has quitado. Mas ahora te otorgaré una gran victoria como compensación de que de regreso de la lucha Andrómaca ya no recibirá de ti la ilustre armadura del Pelida."

La conducta de Héctor con las armas de Patroclo puede ser considerada "error trágico" si entendemos por éste "la clase de acción destructiva que puede cometer un hombre bueno"44. Desde el momento en que el héroe se define en relación con las

42 Aquiles, encolerizado porque Agamenón le ha quitado a Briseida, le ruega a Zeus a través de Tetis que permita a los troyanos acorralar a los aqueos en sus naves junto al mar hasta que reconozcan quién es el mejor entre ellos (I, 407-412). Zeus, entonces, diseña un plan para honrar a Aquiles (II, 3-4).

43 Estamos de acuerdo con Basset, S. E. "Hector's Fault in Honor", TAPhA 54, 1923, 1, 117-127, para quien el gesto y las palabras de Zeus parecen indicar que Héctor ha violado algún tipo de norma que no se explicita. "Hector's fault in honor depends little upon the part which Apollo plays in the death of Patroclus and on his own reputation for courage. It consists in the undue appropriation of glory. There is too much of personal pride in his exultation over Patroclus (...) and too much of personal interest in the pursuit of the immortal steeds. Hector at first sends the armor of Patroclus to the city 'for a glory unto himself,' and finally dons this armor in violation of a fundamental principle of chivalry." (126).

44 Redfield, Naturaleza y Cultura, 121. 
aspiraciones que los demás tienen sobre é ${ }^{45}$, el error es resultado de conducirse más allá de los propios límites en el afán de ajustarse a esas mismas aspiraciones.

De la misma manera, la destrucción de Pompeyo, anticipada en el episodio de Ericto $(\mathrm{VI}, 802-807)^{46}$, se precipita a causa de un conjunto de decisiones que pueden ser nucleadas en la secuencia del error trágico ${ }^{47}$. Así como Héctor comienza a luchar con ferocidad luego de las sanciones de Sarpedón (V, 472-92), Pompeyo decide combatir en Farsalia ${ }^{48}$ presionado por los suyos. Éste será su primer error: la primera de las decisiones que tome

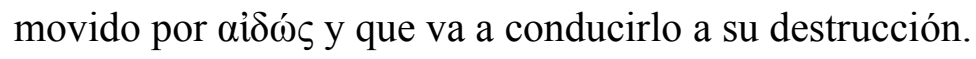

dira subit rabies: sua quisque ac publica fata praecipitare cupit; segnis pauidusque uocatur ac nimium patiens soceri Pompeius, et orbis

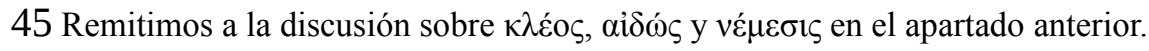
46 Citamos el episodio:

[...] Refer haec solacia tecum, o iuuenis, placido manes patremque domumque

expectare sinu regnique in parte serena Pompeis seruare locum. nec gloria paruae sollicitet uitae: ueniet quae misceat omnis hora duces.

Llévate contigo, oh joven, este consuelo: los manes esperan a tu padre y a su casa en un apacible cobijo, y reservan en la parte serena de su reino un lugar para los Pompeyos. Y que no te perturbe la gloria de una vida breve: ya se aproxima la hora en la que se mezclen todos los generales.

47 Aristóteles (Poet. IV, 1448 b34- 1449 a2) afirma que Homero en la Ilíada y la Odisea esboza los principios de la trama trágica. La literatura crítica en esta vía de análisis ha sido en consecuencia abundante. Destacamos además de Redfield, Naturaleza y Cultura, a Rinon, Y., "A tragic pattern in the Iliad", HSCPh 104, 2008, 45-91 para un estado de la cuestión. Como resumen del problema, citamos:"The Iliad represents man's conflict in life with immanent death. In so far as the idea of conflict is basic to the main theme of the poem the scope of the Iliad is tragic rather than epic, and the two figures in whom the elements of conflict are made most explicit, Achilles and Hector, are tragic rather than epic heroes." (Tait, M., "The Tragic Philosophy of the Iliad", TAPhA 74, 1943, 49-59, p.49).

$48 \mathrm{La}$ lectura de la batalla de Farsalia como un error trágico por parte de Pompeyo es reforzada por el narrador:

hoc placet, o superi, cum uobis uertere cuncta/ propositum, nostris erroribus addere crimen?/ cladibus inruimus nocituraque poscimus arma;/ in Pompeianis uotum est Pharsalia castris. (VII, 5861)

¿Esto les place, oh dioses, cuando tienen el propósito de invertir todas las cosas, añadir el crimen a nuestros errores? Corremos a nuestras destrucciones y pedimos armas que nos destruirán; en el campamento pompeyano, el voto es Farsalia. 
indulgens regno, qui tot simul undique gentis

iuris habere sui uellet pacemque timeret. (VII, 51-55)

Una siniestra rabia los invade: cada uno desea precipitar su propio hado y el de la patria; Pompeyo es llamado lento y temeroso, y que le permite demasiado a su suegro, y que se entrega al gobierno del orbe, ya que desea tener bajo su dominio a tantos pueblos de todas partes al mismo tiempo y teme la paz.

Pompeyo entiende que se enfrenta al error en tanto precipita una destrucción que sería evitable si en ese momento depusiera las armas, y decide combatir dejando en claro que lo hace contra su voluntad.

'si placet hoc' inquit 'cunctis, si milite Magno, non duce tempus eget, nil ultra fata morabor: inuoluat populos una fortuna ruina sitque hominum magnae lux ista nouissima parti. (VII, 87-90)

"Si esto les place a todos," dijo "si el tiempo necesita de un Magno que sea soldado y no general, no demoraré por más tiempo en nada los destinos: que la fortuna envuelva a los pueblos en una misma ruina y que este mismo día sea el último para una gran parte de los hombres."

Sin embargo, la actitud de uno y otro personaje al momento de enfrentar el error es radicalmente opuesta. Mientras Héctor se precipita decidido en el error en un gesto de pura acción pero sumido en la ceguera, Pompeyo sabe que se enfrenta a su error trágico, y se precipita en él con la resignación del que sabe que el error es inevitable.

\section{(...) Sic fatur et arma}

permittit populis frenosque furentibus ira laxat et ut uictus uiolento nauita Coro dat regimen uentis ignauumque arte relicta puppis onus trahitur. (VII, 123-127)

Así habla, y permite a los pueblos tomar las armas y suelta los frenos a los enfurecidos a causa de la ira y, como el marino vencido por el violento Coro, entrega el mando a los vientos y, abandonando su destreza, es arrastrado como una carga inerte de la nave.

El segundo error trágico de Pompeyo será aceptar el consejo de Léntulo en Faselis y dirigirse a Egipto. 
(...) non plura locutus

inpulit huc animos. quantum, spes ultima rerum,

libertatis habes! uicta est sententia Magni. (VII, 453-455)

Sin decir nada más, empujó sus ánimos en esta dirección. ¡Cuánta libertad tienes, esperanza última de las cosas! Fue vencido el parecer del Magno.

Pompeyo pierde nuevamente una batalla. Vencido en Farsalia, se enfrenta en el campo de lo discursivo contra la retórica de Léntulo, superior a la propia. Así como se entregó pasivamente al combate, cede también en sus ideas y se entrega pasivamente a su destrucción, siguiendo un curso de acción que no comparte.

\section{5- Circunstancias de la muerte}

Las secuencias con las que se narran las respectivas muertes de los personajes pueden sintetizarse en el siguiente esquema, abstrayéndolas a principios narrativos.

- $\quad$ Huida de la víctima (personaje que pierde un combate)

- $\quad$ Interrupción de la huida por la traición de un tercer participante

- $\quad$ Muerte de la víctima

- $\quad$ Deshonra de su cadáver

Pompeyo huye de Farsalia y se dirige en primer lugar a Lesbos para reencontrarse con Cornelia. Luego del episodio en Faselis, se dirige a Egipto, donde el gobierno de Ptolomeo XIII debía serle favorable. Cuando arriba a las costas de Egipto, emisarios de Ptolomeo, encabezados por Aquilas, el jefe del ejército, lo invitan a descender de su barco y a llegar a la costa en una nave de menor envergadura. Pompeyo, que entiende qué se esconde detrás del proceder de Ptolomeo, desciende sabiendo que está siendo traicionado.

non ulli comitum sceleris praesagia derant: quippe, fides si pura foret, si regia Magno sceptrorum auctori uera pietate pateret, uenturum tota Pharium cum classe tyrannum. 
sed cedit fatis classemque relinquere iussus

obsequitur, letumque iuuat praeferre timori. (VII, 571-576)

A ninguno de sus compañeros les faltaban presagios del crimen: en efecto, si hubiera existido una lealtad pura, si el palacio se abriera con sincera piedad al Magno, responsable de los cetros, habría estado pronto a venir el tirano de Faros con toda la flota. Pero cede a su destino y accede a abandonar su flota cuando se le ordena hacerlo, le agrada preferir la muerte al temor.

Si bien Cornelia le suplica que no descienda y que emprendan nuevamente la huida, Pompeyo le responde apelando al honor que aún le queda:

remane, temeraria coniunx, et tu, nate, precor, longeque a litore casus expectate meos et in hac ceruice tyranni explorate fidem' dixit. (VII, 579-582)

Quédate, dijo, temeraria esposa, y tú, hijo, les ruego, y lejos de la costa observen mi caída, y en este cuello tengan una prueba de la lealtad del tirano.

En Ilíada, Héctor queda solo frente a las puertas de la ciudad y espera a Aquiles que, invadido de una furia aniquiladora, ha obligado a los troyanos a replegarse y a volver a la ciudad. Mientras lo espera, el terror lo invade y finalmente no puede evitar huir. Emprende una carrera alrededor de la ciudad en la que Aquiles no logra alcanzarlo. A causa de esto, Atenea se presenta ante Héctor con el aspecto de Déifobo y lo detiene en su carrera $(X X, 226)$. Puede afirmarse entonces que Héctor es alcanzado por Aquiles sólo porque es a traición obligado a detenerse. Al igual que Pompeyo, Héctor-demasiado tarde- entiende que ha sido traicionado y que está a punto de morir:

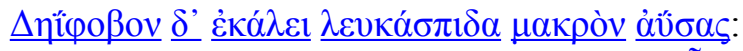

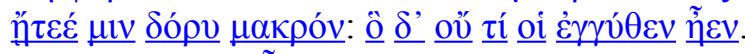

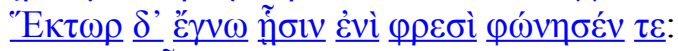

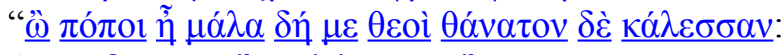

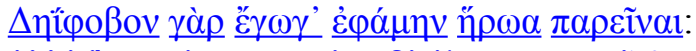

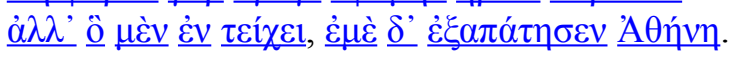

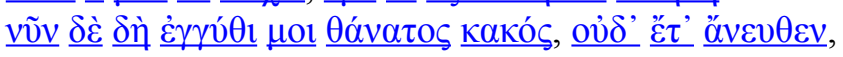

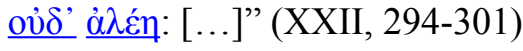

Llamó a Déifobo, el de blanco broquel, con recia voz y le pidió una larga lanza: pero ya no estaba cerca. Héctor comprendió en su corazón y exclamó: 
"¡Ay! Sin duda los dioses ya me llaman a la muerte. Estaba seguro de que el héroe Déifobo se hallaba a mi lado; pero él está en la muralla y Atenea me ha engañado. Ahora sí que tengo próxima la muerte cruel; ni ya está lejos ni es ineludible"

Decide entonces morir de un modo honorable: en el marco de la sociedad de los

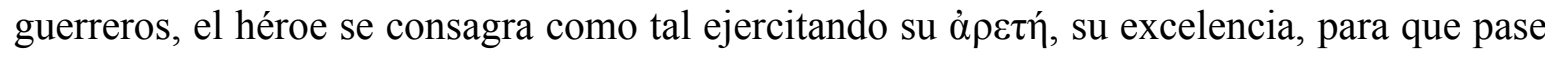

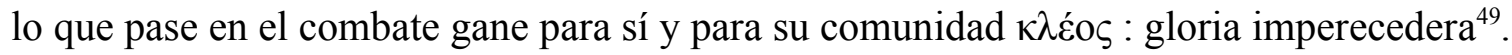

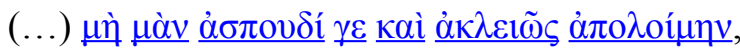

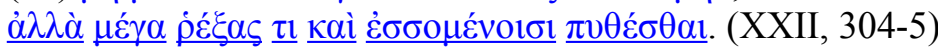

¡Que al menos no perezca sin esfuerzo y sin gloria, sino tras una proeza cuya fama llegue a los hombres futuros!

Héctor enfrenta entonces a Aquiles en combate singular. A pesar de que éste es ayudado por los dioses, Héctor anticipa el golpe y esquiva la lanza que Aquiles le ha arrojado (XXII, 274-276). Luego, cuando Héctor arroja su lanza, acierta su golpe (XXII, 289-292) que sin embargo no logra dañar a Aquiles, porque sus armas han sido fabricadas por los dioses. Esta desigualdad entre los dos personajes al momento del combate permite deducir que Héctor iguala o incluso supera a Aquiles en el combate (Héctor sí logra acertar su tiro), realizándose así en su ỏpetí antes de morir.

Es esta la actitud ante la muerte que adoptará también Pompeyo cuando desciende de su embarcación en las costas de Pharos. En el momento de su muerte se realiza en su $v_{i r t u s}{ }^{50}$, representada en el sentido amplio de fortaleza física y valentía por un lado y de supremacía ética, muy próxima a la apathia estoica $^{51}$, por el otro.

(...) ut uidit comminus ensis, inuoluit uoltus atque, indignatus apertum fortunae praebere, caput; tum lumina pressit continuitque animam, nequas effundere uoces uellet et aeternam fletu corrumpere famam.

49 Para profundizar el problema Redfield, Naturaleza y Cultura, 33 ss.

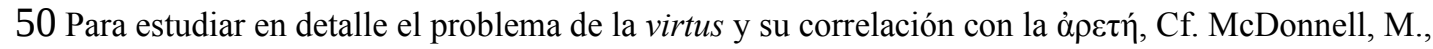
"Roman men and greek Virtus", en Rosen, M. \& I. Sluiter, Andreia: studies in manliness and courage in classical antiquity, Boston, Brill, 2003.

51 Sobre estoicismo en Farsalia, consultar especialmente Sklenár, R., The Taste for Nothingness: a Study of Virtus and Related Themes in Lucan's Bellum Civile. Michigan, The University of Michigan Press, 2003. 
sed, postquam mucrone latus funestus Achillas

perfodit, nullo gemitu consensit ad ictum

respexitque nefas, seruatque inmobile corpus,

seque probat moriens (...) (Luc. VIII, 613-621)

Cuando vio las espadas encima de él, envolvió su rostro y su cabeza, no juzgando digno presentarla descubierta ante la fortuna; entonces apretó sus ojos y contuvo el aliento, no quisiera dejar escapar ningún gemido y así corromper con el llanto su eterna fama. Pero luego de que el funesto Aquilas perforara el costado con la punta de la espada, no le correspondió con ningún gemido y no miró la impiedad acometida, y mantiene el cuerpo inmóvil y se prueba a sí mismo muriendo (...)

Es necesario destacar que si bien no es César quien mata a Pompeyo empuñando él sus propias armas, Pompeyo muere creyendo que César ha ordenado su asesinato y que se le ha adelantado en la huida, llegando antes que él a Egipto:

"(...) quacumque feriris, crede manum soceri (...)" (VIII, 628-629)

Cualquiera sea la mano con la que seas herido, cree que es la de tu suegro.

Con similares palabras, Cornelia expresa la misma idea:

o coniunx, ego te scelerata peremi: letiferae tibi causa morae fuit auia Lesbos, et prior in Nili peruenit litora Caesar (...). (VIII, 639-641)

Oh esposo, yo, criminal, te he aniquilado: la perdida Lesbos fue para ti la causa de la fatal demora, y César llegó primero a las orillas del Nilo.

Una vez que el héroe muere, su antagonista deshonra su cadáver imponiéndole toda clase de vejaciones y, fundamentalmente, negándole su sepultura.

Aquiles mata a Héctor y deshonra su cadáver (XXII, 373-374; 395-398), arrastrándolo ante las murallas de Troya antes de llevárselo a su campamento para allí continuar agrediéndolo (463-465). 


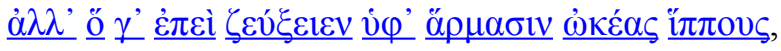

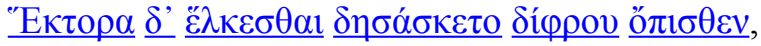

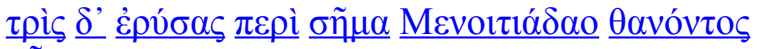

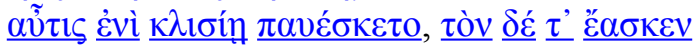

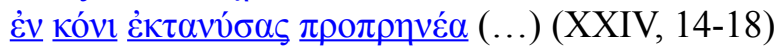

Entonces, después de uncir bajo el carro los ligeros caballos, ataba el cuerpo de Héctor tras la caja para arrastrarlo, le daba tres vueltas alrededor del túmulo del Mecíada muerto y se volvía de nuevo a la tienda a descansar, dejando a aquél extendido de bruces en el polvo $(\ldots)$

En Farsalia, el asesinato de Pompeyo se realiza con especial crueldad: mientras aún agoniza, Aquilas le corta brutalmente la cabeza, cometiendo la impiedad de dejar al descubierto su rostro, gesto que guarda una especial significación en la construcción de la heroicidad del personaje.

nam saeuus in ipso

Septimius sceleris maius scelus inuenit actu, ac retegit sacros scisso uelamine uoltus semianimis Magni spirantiaque occupat ora collaque in obliquo ponit languentia transtro. (VIII, 667-671)

Pues el cruel Septimio en el mismo acto del crimen halla un crimen mayor, pues desgarrando el velo, descubre los sagrados rasgos de Magno moribundo y se apodera de su boca que aún respiraba, y coloca el desfallecido cuello sobre el oblicuo banco.

A continuación arroja su cuerpo por la borda y lleva la cabeza hasta Ptolomeo, quien la hará embalsamar para conservarla como trofeo. Queda su cuerpo varado en la costa, a merced de las olas (698-699), hasta que Cordo improvisa funerales y una sepultura en la costa (VIII, 712-793). Mientras tanto, la corrupción afecta sus restos.

pulsatur harenis, carpitur in scopulis hausto per uolnera fluctu, ludibrium pelagi, nullaque manente figura una nota est Magno capitis iactura reuolsi. (VIII, 708-711)

Es empujado en las arenas, desgarrado en las rocas mientras el agua es absorbida a través de sus heridas, como un juguete del mar, no quedando nada reconocible, el Magno tiene por única señal la pérdida de su cabeza cortada. 
Esta conducta para con el cuerpo del enemigo derrotado atraviesa toda Ilíada como amenaza, como el límite último del horror de la guerra que sin embargo nunca llega a cumplirse: los dos cadáveres puestos en juego en el argumento, el de Patroclo y el de Héctor, son finalmente devueltos y reciben, aunque tarde, sus funerales. Si bien el examen de las consecuencias de la profanación de los cadáveres excede los límites de este trabajo, es necesario destacar que la negación de los funerales y el maltrato del cuerpo representan tanto en la comunidad de guerreros griega como en la Roma de la República y del Imperio una doble afrenta. En primer lugar, al muerto: el cuidado de su cuerpo y la realización de sus funerales conllevan la dignificación del individuo en tanto se construye una memoria de él destinada a durar. Al mismo tiempo, el tratamiento del cuerpo, sea cual fuere el método funerario empleado, arrebata al individuo de la naturaleza que en forma de corrosión lo aparta de la cultura. Sepultar a un muerto es una manera simbólica de conservarlo en los límites de la comunidad ${ }^{52}$, e incluso, si se contemplan las creencias sobre la imposibilidad de descanso ulterior para el muerto no sepultado, realizar sus funerales es el gesto final de la comunidad en su beneficio. En palabras de Ericto,

a miser, extremum cui mortis munus inique

eripitur, non posse mori (VI, 724-725)

Oh desgraciado, aquel a quien se le arrebata el último don de la muerte injustamente: no poder morir.

En segundo lugar, realizar el correspondiente funeral a los muertos es también la posibilidad de que la comunidad sane la herida que deja la súbita desaparición de uno de sus miembros. Es esta necesidad la que hace que Príamo se dirija hasta el campamento aqueo para pedir la devolución del cadáver de Héctor (XXIV, 486-506), por el cual paga una importante recompensa (XXIV, 228-237).

Si hasta el momento detectamos simetrías estructurales en la constitución de los personajes, el trazado de este paralelo podría reforzase en la lectura de IX, 950-999, donde Oxford, Blackwell Publishing Ltd., 2007; De Coulanges, F., La Ciudad Antigua, México DF, Porrúa Ed., 1996 (1864), 5-15; Redfield, Naturaleza y Cultura, 127-143. 
se narra cómo César visita las ruinas de Troya en su camino hacia Egipto. Entre los pasajes en los que Lucano elabora la materia histórica con mayor libertad, éste es quizás el más evidente desde el momento en que ninguna otra fuente o narración contemporánea registra el paso de César por Troya ${ }^{53}$. La presencia del episodio en el conjunto es en consecuencia relevante $^{54}$, es decir, la secuencia de César paseando por las ruinas de Troya está allí por algún motivo, parafraseando en estos términos a Sperber \& Wilson (1986). En consonancia con nuestra lectura, su función sería explicitar la conexión entre la narración de la guerra civil y la guerra de Troya tal como es narrada en Ilíada. A su vez, una secuencia en concreto dentro del episodio respaldaría nuestra lectura: mientras César camina entre los restos de Troya, distraídamente se detiene sobre los restos del sepulcro de Héctor.

(...) securus in alto gramine ponebat gressus: Phryx incola manes Hectoreos calcare uetat. (IX, 975-977)

Despreocupado, caminaba por la alta hierba: el habitante frigio le prohíbe pisar los manes de Héctor.

El pasaje tendría por fin volver explícitas las conexiones macroestructurales entre ambos textos y especialmente la conexión entre los personajes de Héctor y Pompeyo. El gesto de César triunfador pisando los manes de Héctor, derrotado en Troya, obliga a pensar en Pompeyo, derrotado en Farsalia y asesinado en Egipto. La conexión incluso se consolidaría si se tiene en cuenta que en VI, 350 se explica el origen de la tierra de Farsalia y se la presenta como la tierra de Aquiles, aequorei regnum Pharsalos Achillis. La identificación de César con Aquiles y de Pompeyo con Héctor se consolidaría en consecuencia en este episodio en el que el escenario, las ruinas de Toya, se presenta como marco de integración que funde en un mismo relato dos relatos, dos conflictos, dos textos y dos planos de realidad: el mito ${ }^{55}$ y la historia.

53 Cf. Zwierlein, O., "Lucan's Caesar at Troy", en: Tesoriero, C. (ed.), Oxford Readings in Classical Studies: Lucan, Oxford, Oxford University Press, 2010, 411-432.

54 Utilizamos el término relevancia en sentido puramente técnico. Siguiendo a Willson \& Sperber, "Sobre la definición de relevancia", es relevante un estímulo que mediante la activación de ciertos contextos en el receptor permite la construcción de explicaturas.

55 Tomamos "mito" en términos de García Gual, según el cual "mito" es un relato tradicional que refiere la actuación memorable y ejemplar de unos personajes extraordinarios en un tiempo prestigioso y lejano (García 


\section{Consecuencias y conclusiones}

El análisis macroestructural ${ }^{56}$ presentado en este trabajo permite en principio formalizar la conexión entre ambos textos, la cual en una lectura superficial se hace evidente a partir del reconocimiento de escenas o de rasgos que resultan familiares a un lector competente en los contextos que la literatura de este período supone ${ }^{57}$. Un estudio de esta naturaleza permite en primer lugar superar la búsqueda de calcos lingüísticos como única forma de vinculación de textos. Los cruces estructurales entre relatos, que no aparecerán quizás realizados en la selección léxica, permite que el receptor realice conexiones entre el texto que está siendo procesado y otros que forman parte de su acervo cultural, su contexto, y desde esa conexión producir nuevos significados. En otras palabras, las conexiones intertextuales operan a nivel léxico y a nivel macroestructural y habilitan la construcción de sentido de una manera dinámica en tanto exigen la participación del receptor en la construcción, en última instancia, del texto ${ }^{58}$.

La descomposición de los personajes de Pompeyo y de Héctor en sendos haces de rasgos intensionales ${ }^{59}$ permitió explicitar los fundamentos de lo que intuitivamente se percibe como un simple parecido. En otras palabras, el análisis realizado pondría en relieve los estímulos ostensivos que permiten la construcción de una "explicatura" difusa, que se manifiesta como una "cita cultura" 61.

Gual, C., Introducción a la mitología griega, Alianza Editorial, Madrid, 2006, 22).

56 Seguimos a Van Dijk (Text and Context. Explorations in the semantics and Pragmatics of Discourse, Longman Linguistic Library 21, London, 1977; id. Macroestructures. An Interdisciplinary Study of Global Structures in Discourse. Cognitions and Interaction, Hillsdale, Lawrence Erlbaum, 1980) en tanto las categorías de macroestructura (contenido semántico global que representa el sentido del texto) y superestructura (esquema básico que organiza la información contenida en un texto y que lo clasifica por eso dentro de un tipo) nos resultan productivas para el análisis de las inferencias derivadas del análisis estructural. 57 El destinatario ideal prefigurado por Farsalia conoce la historia y la literatura contemporánea al momento de producción y de los siglos precedentes en tanto forman parte de su acervo cultural.

58 Nuestro análisis parafrasea la teoría de la relevancia, la cual puede recuperarse de Willson \& Sperber, "Sobre la definición de relevancia".

59 Característica que aporta a la descripción de un referente seleccionando propiedades que definen la intersección entre los conjuntos definidos por cada rasgo.

60 Wilson \& Sperber, "Sobre la definición de relevancia".

61 Maingueneau, D., Initiation aux méthodes de l'analyse de discours. Problèmes et perspectives, Paris, Hachette, 1976, 22-23. 
Para finalizar, queremos destacar dos consecuencias interpretativas de una lectura comparativa como la desarrollada en este trabajo. La primera inferencia que se extrae del paralelo es la idea de repetición. Dos guerras, dos enfrentamientos de dos individuos que se miden en su grandeza (el aspecto positivo o negativo o relativo de la misma queda fuera del análisis porque implica la participación de un alto grado de subjetividad). La segunda inferencia, la identidad. Así como existe una analogía entre los personajes y sus conflictos, existe una analogía a nivel superestructural: los relatos de Ilíada y Farsalia se corresponden en que ambas son narraciones (identidad superestructural) y que ambas relatan un conflicto análogo (identidad macroestructural) que termina finalmente por provocar una identidad de mayor trascendencia que es la de mito e historia.

La lectura propuesta en el presente trabajo puede insertarse en la línea de las lecturas decadentistas en Farsalia ${ }^{62}$. Por un lado, si la historia se repite, si Roma es una nueva Troya y como ella está condenada a la ruina, nada impide que en un futuro un nuevo estado poderoso se convierta en las ruinas de otro que lo recuerde en su literatura ${ }^{63}$. De esta manera, lo que se construye en Farsalia es una cosmología, una visión del mundo y de sus acontecimientos. Si esto es así, las lecturas acotadas al compromiso (o descompromiso) político de la obra quedan, justamente, $\operatorname{acotadas}^{64}$. Sin salir de los límites de Farsalia, por otro lado, la idea de la repetición del conflicto vacía políticamente la lectura en tanto se deduce que lo que queda de un conflicto (de estas características al menos) son los caracteres de sus participantes. Cuando a la narración histórica se la despoja de los contextos que la vuelven significativa a nivel explícito en términos ideológicos, sólo queda su superestructura y esqueletos de rasgos, personajes, luchando entre ellos. Se puede imaginar un Lucano seducido por los rasgos de los protagonistas de la historia reciente a los que convierte en personajes. La fascinación por lo horroroso ${ }^{65}$ consiste en la estetización de lo cotidiano, en la conversión de la historia en literatura. En ese sentido, entonces, estaría hablando el narrador de Farsalia, Lucano mismo:

62 Cf. Sklenár̆, The Taste.

63 Ahl, Lucan, 217.

64 En este sentido, nuestra propuesta suma a la lectura de Johnson, Momentary Monsters, para quien Farsalia no es una obra proselitista, y que suponerlo recorta las posibilidades interpretativas.

65 Johnson, Momentary Monsters. 
o sacer et magnus uatum labor! omnia fato eripis et populis donas mortalibus aeuum. (IX, 980-981)

¡Oh, sagrada y grande es la labor de los poetas! Arrebatas todo al destino y das a las gentes mortales la eternidad.

\author{
Malena Trejo \\ IdIHCS (CONICET/ UNLP) \\ malena.trejo.mt@gmail.com
}

\title{
Resumen:
}

El tratamiento de los personajes de César y de Pompeyo en Farsalia presenta fisuras o inconsistencias que la literatura crítica ha intentado salvar mediante diversas construcciones de sentido. Entre estas diversas vías interpretativas destacan las que realizan lecturas intertextuales entre Farsalia e Ilíada, especialmente en relación al modo según el cual en una y otra obra opera el código heroico (Anderson, 1957; Hardie, 1993; Green, 1991).

Es clásica en esta materia la propuesta de Von Albrecht (1970) centrada en la identificación de César con Aquiles y de Pompeyo con Agamenón. Nuestro trabajo retoma la comparación de César con Aquiles, pero refuta la existente entre Pompeyo y Agamenón, presentando para eso un paralelo con Héctor. Nuestra hipótesis permitiría arrojar nueva luz sobre la lectura global que Lucano realiza sobre las guerras civiles.

Palabras clave: Lucano- Ilíada- Intertextualidad- héroe- memoria

\begin{abstract}
:
The characters of Caesar and Pompey in Pharsalia show certain inconsistencies that critical literature has attempted to explain by means of different strategies for building of meaning. A distinctive one among these is the intertextual reading between Pharsalia and The Iliad, concerning mainly the heroic code (Anderson, 1957; Hardie, 1993; Green, 1991).

This reading stems from von Albrecht (1970), who stablishes a parallelism between Caesar and Achilles, and between Pompey and Agamemnon. Our paper departs from von Albrecht as far as the second one is concerned, in order to set a new comparison between Pompey's fictional representation and Hector's character. Our objective is to rethink the intertextual reading of Pharsalia, and thereby shed light on Lucan's interpretation of the Civil Wars.
\end{abstract}

Keywords: Lucan- Iliad- intertextuality- hero- memory

RECIBIDO: 23-6-2017 - ACEPTADO: 15-10-2017 